\section{Correspondence}

https://doi.org/10.11646/zootaxa.5068.4.10

http://zoobank.org/urn:lsid:zoobank.org:pub:88C9F6A1-3DDF-47DC-9235-3B7C9241B5D6

\title{
Metapocyrtus um sp. nov., a new weevil species (Coleoptera, Curculionidae, Entiminae, Pachyrhynchini) from Davao City, Mindanao Island, Philippines
}

\author{
ANALYN A. CABRAS ${ }^{1 *}$, ATHENA W. LAM ${ }^{2} \&$ MATTHEW H. VAN DAM ${ }^{2}$ \\ ${ }^{1}$ Coleoptera Research Center, Institute of Biodiversity and Environment, University of Mindanao, Davao City, 8000, Philippines \\ ${ }^{2}$ Entomology Department, Institute for Biodiversity Science and Sustainability, California Academy of Sciences, San Francisco, Cali- \\ fornia, 94118, U.S.A. \\ "Corresponding author. !" ann.cabras24@umindanao.edu.ph; ○ https://orcid.org/0000-0002-0980-1651
}

The genus Metapocyrtus Heller 1912 is the most speciose and complex among the tribe Pachyrhynchini with 7 subgenera and more than 200 described species (Schultze, 1925; Bollino et al., 2020; Cabras et al., 2021). The genus is endemic to the Philippines but with several records from Japan, Malaysia and Taiwan due to importation of plants or plant products (Yoshitake \& Tsuji, 2019). Like the other members of the Pachyrhynchini, Metapocyrtus have fused elytra and are incapable of flight which has resulted in high endemism and narrow geographic ranges often confined to an island or mountain range. During the last joint expedition conducted by the University of Mindanao and California Academy of Sciences, one species of Metapocyrtus was found to be new to science. In this paper, the new species is described and illustrated with a brief description of its habitat. The CO1 (cytochrome oxidase) sequence for the species is deposited in the NCBI database.

The specimens examined for this study were collected through sheet beating and hand picking and killed in vials with ethyl acetate. Morphological characters were observed under Luxeo 4D and Nikon SMZ745T stereomicroscopes. The treatment of the genitalia including the method of endophallus eversion was identical to that described by Van Dam (2014). Stacked digital images were taken following Cabras et al. (2021) except for the endophallus (taken with a 65mm macro lens), and the male habitus which were stacked and processed using Zerene Stacker. Measurements presented in this paper follow Yoshitake (2011). For DNA preparation, DNA was extracted from the tissue surrounding the endophallus of the holotype using DNEasy tissue kit (Qiagen, Hilden-Germany). The PCR primers and thermocycler conditions follow those in Morinière et al. 2016. The PCR product was sequenced using an ABI-3130xl Genetic Analyzer. The sequence was corrected and reconstructed using the Sequencher ${ }^{\circledR}$ version 5.4.6 DNA sequence analysis software, Gene Codes Corporation, Ann Arbor, MI USA.

Comparative materials and specimens used in the study are deposited in the following institutional collections:

CASENT California Academy of Sciences Entomology Collection,

PNM National Museum of Natural History (PNMNH) under the National Museum of the Philippines

UMCRC University of Mindanao Coleoptera Research Center, Davao City Philippines.

\section{Metapocyrtus um Cabras and Van Dam, sp. nov.}

(Figs. 1, A-D)

http://zoobank.org/urn:lsid:zoobank.org:act:40CAA13D-F599-4ADF-B123-032EA0303A97

Holotype (Figs. 1, A-B), male: Philippines-Mindanao / Marilog / Davao City / July 6, 2018 / 7.488387N, 125.255635E / coll. Van Dam (typed on white card) // HOLOTYPE male / Metapocyrtus um / CABRAS \& VAN DAM, 2021 (typed on red card) (PNMNH). Paratypes (2̧̄̋,, 2우): 1ㅇ, Philippines-Mindanao / Marilog / Davao City / July 6, 2018 / coll. Cabras (UMCRC); $2 \hat{\jmath} \hat{\jmath}, 1+$, same data as holotype (CASENT). All paratypes with additional red label: PARATYPE / Metapocyrtus um / CABRAS \& VAN DAM, 2021.

Diagnosis. Metapocyrtus um is distinct among the endemic Metapocyrtus in Mindanao. The unique coloration of the elytra with intervals I-III reddish brown, the ornamentation of the pronotum and the elytra with sparse light-yellow 
ochre and turquoise round scales on the dorsolateral sides, and the ovate elytra with the dorsum moderately and uniformly convex in profile with a steep apical declivity, easily distinguishes this species from its congeners.

Description. Male. Dimensions : LB : 9.0-9.9 (holotype 9.0mm). LR : 2.0-2.2 (2.0mm). WR : 1.2-1.32 (1.2mm). LP : 3.2-3.52 (3.2mm). WP : 3.0-3.3 (3.0mm). LE: $6.5-7.15$ (6.5mm). WE: 5.0-5.5 (5.0mm). N=2.

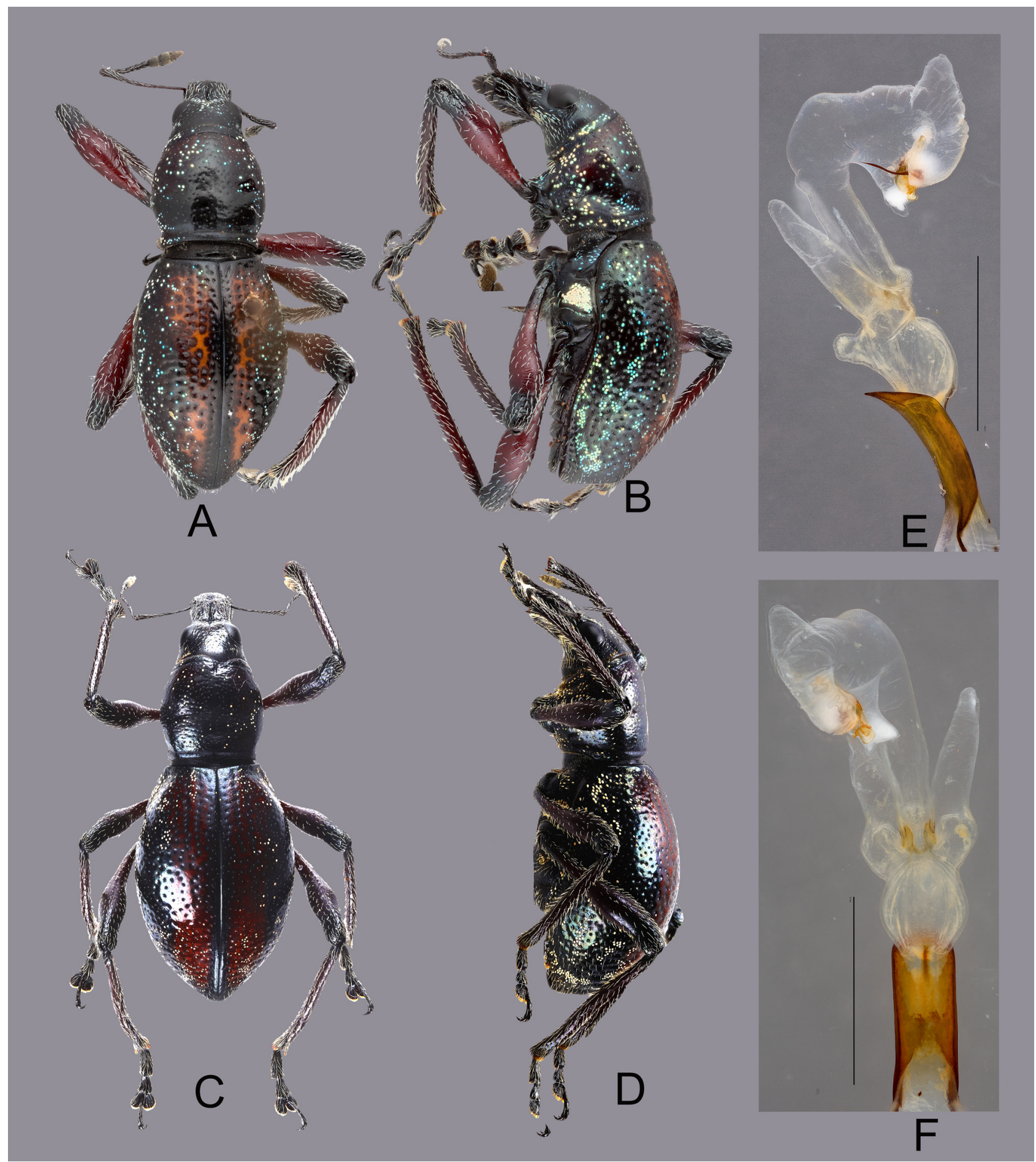

FIGURE 1. Metapocyrtus um sp. nov. A male holotype, dorsal view. B idem, lateral view. C female paratype, dorsal view. D idem, lateral view. E everted endophallus, lateral view. F everted endophallus, dorsal view (scale bar $2 \mathrm{~mm}$ ).

Integument of elytra and legs reddish brown and black; head, rostrum, antennae and tarsi black. Body surface, rostrum, head, and underside with a weak luster. Body subglabrous. Head finely punctured, sparsely minutely pubescent, dorsally with dispersed metallic pale-yellow ochre round to elliptic scales, with pale-yellow ochre setae on lateroventral parts; forehead between eyes not depressed, with scattered light-yellow ochre round scales and sub-adpressed white setae. 
Rostrum weakly rugose on basal half, finely punctured on apical half, nearly twice longer than wide (LR/WR:2/1.2mm), bearing whitish, moderately long suberect adpressed setae on dorsum and longer whitish suberect setae on lateral and ventral surface interspersed with adpressed hairs; transverse basal groove distinct but not reaching lateral margin; longitudinal groove along midline distinct; dorsal surface almost flat, apex weakly convex. Eyes medium-sized, feebly convex. Antennal scape and funicle of almost same length, covered with suberect adpressed fine light-colored hairs. Funicular segments I and II almost of same length, three times longer than wide; segments III-VII nearly as long as wide; club sub-ellipsoidal, nearly 3 times longer than wide. Prothorax sub-globular, nearly as long as wide (LP/WP:3/3.2mm), surface black with a tinge of red on apical half, finely punctured, sparsely minutely pubescent, widest at middle, nearly flattish on dorsal surface, sparsely covered with light yellow ochre and turquoise round scales, with turquoise setae on lateral surface. Elytra ovate (LE/WE:6.5/5mm), slightly wider and twice longer than prothorax (WE/WP: 5/3mm, LE/LP: $6.5 / 3.2 \mathrm{~mm}$ ), finely punctured, minutely pubescent, dorsum moderately uniformly convex in profile, with steep apical declivity, apex with dense long white hairs; body surface mostly black except for intervals I-III reddish brown, sparsely covered with light-yellow ochre and turquoise round scales on dorsolateral side which become denser towards lateral margin. Legs with moderately clavate femora. Femora red in color, black toward apical margin, densely covered with suberect long white setae. Tibiae covered with suberect long white setae, weakly serrate along inner edge. Fore tibiae with mucro at apex. Tarsomeres covered with sparse pubescence. Coxae covered with pale bluish to yellowish setae and with sparse turquoise elliptical scales. Mesoventrite covered with light colored subadpressed setae. Metaventrite with light colored adpressed setae and dense light yellow-ochre round scales on lateral sides. Ventrite I depressed at middle with colored adpressed setae, very dense yellow adpressed setae towards middle, sparse light yellow-ochre and turquoise round scales towards lateral margins. Ventrite II to V sparsely covered with adpressed setae. Ventrite V flattened, apical half finely densely punctured, with minute hairs and long whitish and bluish setae.Male endophallus as shown in Figure $1 \mathrm{E}, \mathrm{F}$.

Female. Dimensions: LB: $12.0-12.7 \mathrm{~mm}$ : LR: $2.0-2.1 \mathrm{~mm}$ : WR: $1.7-1.8 \mathrm{~mm}$. LP: $3.0-3.2 \mathrm{~mm}$. WP: $4.2-4.5 \mathrm{~mm}$. LE: 9.0-9.5mm. WE: $6.9-7.5 \mathrm{~mm}$. $\mathrm{N}=2$.

Etymology. The new species is named after the initials of the University of Mindanao, UM. The color of the new species is reminiscent of the university's color symbol.

Distribution. Metapocyrtus um is known from Mt. Malambo, Marilog, Davao City.

DNA barcode. The sequence record is deposited in the NCBI (National Center for Biotechnology Information) database with accession number: OL333551.

\section{Brief habitat description for Metapocyrtus um}

The new species was collected in the closed canopy of Mt. Malambo in Marilog District, Davao City at an elevation of between 1100-1300 m. Marilog District, which lies between Davao region and Bukidnon, is characterized by a mixture and of course the NCBI number of old growth primary and secondary forests. Mt. Malambo is one of the isolated hills that remains intact in the area despite the conversion of neighboring areas to tourist resorts. The biotope where the new species was collected is covered by dense vegetation; however, the identity of the plant species that the specimens were collected from remains unknown. Metapocyrtus um seems to be a rare species and confined so far to Marilog District although more sampling is needed to map out the actual distribution of the species.

\section{Acknowledgments}

We express our gratitude to Dr. Milton Norman Medina and Chrestine Torrejos for the help in collection; Dr. Arvids Barševskis from Daugavpils University, Latvia; Dr. Hiraku Yoshitake from Institute for Agro-Environmental Sciences, NARO (NIAES), Tsukuba, Japan; Dr. Klaus-Dieter Klass and Olaf Jäger from Senckenberg Natural History Collections, Dresden, Germany for their assistance during the visit of the first author.

\section{References}

Bollino, M., Medina, M.N. \& Cabras, A.A. (2020) Three new Metapocyrtus Heller, 1912 (Curculionidae, Entiminae, Pachyrhynchini) from Mindanao Island, Philippines. Journal of Tropical Coleopterology, 1 (1), 26-38.

Cabras, A.A., Medina, M.N. \& Bollino, M. (2021) Two new species of the genus Metapocyrtus Heller, 1912 (Coleoptera, Curculionidae, Entiminae, Pachyrhynchini), subgenus Orthocyrtus Heller, 1912, from Mindanao Island, Philippines. ZooKeys, $1029,139-154$. 
https://doi.org/10.3897/zookeys.1029.63023

Morinière, J., Cancian de Araujo, B., Lam, A.W., Hausmann, A., Balke, M., Schmidt, S., Hendrich, L., Doczkal, D., Fartmann, B., Arvidsson, S. \& Haszprunar, G. (2016) Species Identification in Malaise Trap Samples by DNA Barcoding Based on NGS Technologies and a Scoring Matrix. PLoS ONE, 11 (5), e 0155497.

https://doi.org/10.1371/journal.pone.0155497

Schultze, W. (1925) A monograph of the pachyrrhynchid group of the Brachyderinae, Curculionidae: Part III. The genera Apocyrtidius Heller and Metapocyrtus Heller. Philippine Journal of Science, 26, 131-310.

Van Dam, M.H. (2014) A Simple, Rapid Technique for the Inflation of the Endophallus, with Particular Focus on the Curculionoidea (Coleoptera). The Coleopterists Bulletin, 68, 263-268. https://doi.org/10.1649/0010-065X-68.2.263

Yap, S.A. \& Gapud, V.P. (2007) Taxonomic review of the Genus Metapocyrtus Heller (Coleoptera: Curculionidae: Entiminae). The Philippine Entomologist, 21 (2), 115-135

Yoshitake, H. (2011) A new species of the subgenus Artapocyrtus of the genus Metapocyrtus (Coleoptera: Curculionidae: Entiminae) from Mindanao, the Philippines. Esakia, 50, 115-119.

Yoshitake, H. \& Tsuji, N. (2019) Occurrence of Metapocyrtus (Trachycyrtus) adspersus Waterhouse (Coleoptera: Curculionidae: Entiminae) in Japan and Singapore. Elytra, Tokyo, New Series, 9 (1), 177-179. 